\title{
Xianzhong Liu* \\ Developments in Russian Historical Studies in China since Reform and Opening-up
}

https://doi.org/10.1515/cjss-2021-2004

Published online September 3, 2021

Abstract: It was not until China's reform and opening-up that the study of Russian history in China really began. From the reform and opening-up to the present, the study of Russian history in China could be divided into two stages: from the reform and opening-up to the disintegration of the Soviet Union as the first stage; from the disintegration of the Soviet Union to the present is the second stage. During the first stage, Russian history researchers in China basically aimed to throw off shackles on their academic minds, set the chaotic academia straight, and break through the rigid research paradigm set by the History of the All-Union Communist Party (Bolsheviks): A Short Course. However, due to the lack of information exchange and new materials for reference, some articles published at that time appeared to be vague and general with very limited perceptions. Some articles completely broke the connection between Lenin era and Stalin era, and often judged Stalin by Lenin as a standard, and without taking Lenin and Stalin both as subjects for academic research. After the collapse of the Soviet Union, a large numbers of research results and new materials were published, which greatly promoted China's Russian history studies into a new stage. Compared with the first stage before the disintegration of the Soviet Union, the second stage in Soviet history studies features more in-depth research and more specific research questions with basic innovation achieved in historical facts. China's study of Russian history in the future should focus on using new materials, sorting out historical facts and innovating research methodology, aiming to build an academic system, discourse system and discipline system for itself.

The Russian history here refers to the history of Russia from ancient times to the present, which includes the period of Russia before the October Revolution, the period of the Soviet Union after the October Revolution, and the period of the Russian Federation after the collapse of the Soviet Union.

*Corresponding author: Xianzhong Liu, Research Fellow, Institute of Russian, Eastern European \& Central Asian Studies, Chinese Academy of Social Sciences, Beijing, China,

E-mail: oysxzliu@163.com

Ә Open Access. ๑ 2021 Xianzhong Liu, published by De Gruyter. (cc)BY the Creative Commons Attribution 4.0 International License. 
Keywords: Russian historical study in China, historiography, reform and opening-up, the collapse of the Soviet Union

Russia is a major country, highly consequential on the international community regarding the global balance of power, peace, and stability. As China's largest neighbor, Russia shares a long border with China. Equally long is the history of the Sino-Russia exchange. The study of Russia can be traced back to the Qing Dynasty, with texts detailing Russian customs and social backgrounds. After the founding of the People's Republic of China in 1949, research on the Soviet Union gained prominence in China because of the special relationship between the two countries. Rigorous Russian history studies as a true academic discipline began after the reform and opening-up. The author believes that the study of Russian history in post-1978 China has gone through two paradigm shifts: (1) from the reform and opening-up to the collapse of the USSR; 2) from the collapse of the USSR to the present.

\section{From the Reform and Opening-up to the Collapse of the Soviet Union: The Construction, Achievements, and Issues of Initial Russian Historical Studies in China}

From the late 1970s to the early 1990s, it was the beginning of China's reform and opening-up and marked the gradual easing and normalization of Sino-Soviet relations. This period coincided with the academic renaissance in China. The nascent Russian historical studies saw a great deal of development during this period. In this first academic paradigm, scholars moved away from the single-dimensional ideological narrative of the past - aggression and anti-aggression - to encompass the political, economic, cultural, and diplomatic spheres.

As China began practicing the reform and opening-up policy, historians of Russian studies were tasked with finding the answers to the very practical questions raised during this time. Consequently, research reflected and responded to this need. Another trend was a critique of the conservative influences of the past. The mark of this first paradigm was the liberation of academic pursuit from the conservative stance towards a more rigorous academic field. For the first time, scholars broke free of the fixed outline from the History of the All-Union Communist Party (Bolsheviks): A Short Course to reflect and reconstruct the field. As with any nascent field, many questions surfaced through academic scrutiny accompanied by great debates on various issues. 
This was a flourishing period for Russian history research in China. Academic institutions, journals, and organizations came out almost overnight, and many groundbreaking achievements were made.

First, many academic institutions, journals, and organizations were founded, in addition to those that existed previously, to study the USSR. Pre-existing organizations include the Institute of the Soviet Union and Eastern European Studies of the Chinese Academy of Social Sciences (later changed into the Institute of Russian, Eastern European \& Central Asian Studies after 1991), and the Institute of the Soviet Union and Eastern Europe Studies at the Renmin University of China. New research institutes include, among others: The USSR Eastern European History Research Office of the Institute of World History of the Chinese Academy of Social Sciences, The USSR Research Institute of Shanghai Foreign Language College, The Soviet Research Institute of Jilin University, The Research Institute of Soviet Studies at Anhui University (renamed the Russia Research Institute in 1993), The Soviet Studies Research Institute of Heilongjiang University, The Research Office of Soviet Studies in Xinjiang University, The Soviet Research Office of Lanzhou University's History Department, and The Soviet Union Research Office of the Department of History of Shaanxi Normal University.

These institutions have launched their own research journals as academic exchange outlets. For example, Institute of the CASS Soviet Union and Eastern European Studies issued the journal Soviet Union and Eastern European Studies (first published in 1981 and renamed Eastern European Central Asian Studies and later Russian, Eastern European \& Central Asian Studies after 1991), and the Translation Series on Soviet Studies; the Soviet Studies Reference (quarterly) was issued by The USSR Research Institute of Shanghai Foreign Language College (first published in 1980, and then renamed to Soviet Studies in 1990 and International Review after 1991); Social Science Research of the Soviet Union was issued by the Soviet Institute of Jilin University (first published in 1985); the Research Institute of Soviet Studies at Anhui University ran the Research References on Soviet Studies (first published in 1981 and changed to Russian Studies in 1993, and now called Russian Cultural Studies); the Soviet Studies Research Institute of Heilongjiang University ran the Soviet Studies; East China Normal University printed the Soviet Union and Eastern Europe Today (renamed Eastern Europe and Central Asia Today after 1991, and now published under Russia Studies); the Research Office of Soviet Studies in Xinjiang University ran the Soviet Research Reference (first published in 1980); the Soviet Union Research Office of the Department of History of Shaanxi Normal University ran the History of the Soviet Union (formerly the Selected Translations of the History of the Soviet Union, founded in 1979, later renamed The History of the Soviet Union in 1982, and ended 
in its 1993 issue); The History of the Soviet Union was founded in 1983 by the Soviet Research Office of Lanzhou University's History Department; and the Selected Translation of Historiography was issued by the Department of History, Beijing Normal University (first published in 1980). Among these institutes, two stood out with their respective journals for their focus on historical studies, that of Shaanxi Normal University and its History of the Soviet Union, and Lanzhou University and its History of the Soviet Union. In addition, a number of relevant academic organizations have emerged. For example, the China Research Association for Sino-Russia Relations was established in November 1978. In September 1982, the Chinese Society for Soviet-Eastern European Society was established in Shanghai (now the Chinese Society for Russian, Eastern European, and Central Asian Study). And the Historical Association for the Soviet Union and Eastern Europe of China was established in Shaanxi Normal University in 1985. Academic activities were conducted with rigor and depth during this time, which produced quality research in Russian history and gave rise to a new generation of outstanding scholars.

Content-wise, the research of this period is characterized by a breakaway from the domination of the History of the All-Union Communist Party (Bolsheviks): $A$ Short Course, and a reflection and reconstruction of the field. A number of foundational research works were born in this period, including but not limited to, the first general Russian history compiled by Chinese scholars, The Compendium of the General History of Russia (2 Volumes) edited by Sun Chengmu, Liu Zuxi, and Li Jian, and published by the People's Press in 1986. The Revolution and Construction of the Soviet Union was an internal publication by Ye Shuzong in 1986 for the Shanghai Federation of Philosophical and Social Science Associations - this is the first Soviet history written by Chinese scholars. The Modern Soviet History (1917-1945), edited by Zhang Yide, and published by Jilin Literary and History Press in 1987, is the first published history of the Soviet Union by Chinese scholars. General historical publications also include An Outline of Soviet Union History (1917-1937), edited by Chen Zhihua (two volumes) (People's Press, 1991); The New History of the Soviet Union (1917-1985), by Zhou Shangwen, Ye Shanzong, and Wang Side (Shanghai People's Press, 1991), which was later updated and renamed the History of the Rise and Fall of the Soviet Union, expanding to incorporate the collapse of the Soviet Union. Zhou et al. systematically compiled the entire history of Russia, from the October Revolution to the collapse of the Soviet Union. Liu Keming and Jin Hui edited the Seventy Years of Political and Economic System of the Soviet Union (China Social Science Press, 1990); and Lu Nanquan et al. authored the Seventy Years of Economic Development in the Soviet Union (Mechanical Industry Press, 1989). 
There are also some monographs written during this time, including: Sun Chengmu, Li Xianrong, and Kang Chunlin's History of the October Revolution (SDX Joint Publishing Company, 1980), Li Xianrong's Trotsky Critical Biography (China Social Science Press, 1986), Wen Yi, Ye Shuzong's Biography of Bukharin (Jilin Education Press, 1988), Liu Zhi's Study on the Socialist Path of the Soviet Union (Shaanxi Normal University Press, 1989), and Lin Jun's Foreign Relations between China and the Soviet Union (1917-1927) (Heilongjiang People's Press, 1990 edition). Additionally, the SDX Joint Publishing Company published a compilation of historical research in 1985 titled The Modern Historical Studies of the Soviet Union.

A number of reference books and collections were also published during the period. Reference books include the Sino-Soviet Relations Dictionary by Xia Lingen and Yu Xiyuan (Dalian Press, 1990), and The Historical Dictionary of the Soviet Union edited by Chen Zhihua (Jilin Literature and History Press, 1991). Important manuscripts include the Seventy Years of Economic Development in the Soviet Union (Mechanical Industry Press, 1989) by Lu Nanquan et al., The History of Trade between China and the Soviet Union (China Foreign Economic and Trade Press, 1991) by Meng Chuan, and the Selected Documents from Archives Concerning SinoRussian Relations in Qin Dynasty, compiled by the First Historical Archives of China (series 1 and 3) (Zhonghua Book Company, 1981 and 1979) among many others.

This period marks China's first explorations in reform and opening-up. Historical studies based on the Soviet Union provided practical reference as China carved out its own path by aiding policy implementation and providing theoretical support. Therefore, the academic publications of this period mainly had practical purposes with themes such as the October Revolution, Wartime Communism, The New Economic Policy, Lenin's Thoughts in his later years, Bukharin Ideology, Stalin's agricultural collectivization, Stalin's system, and Khrushchev's reform (Chen, 1991, pp. 265-314; Liu, 1984).

Scholars contributed to different perspectives and put forward many unique opinions through their discussions. This period is seminal for China's Russian historical research, partly because it laid down a solid foundation for future research, and partly because the studies have prepared an academic basis and support for the reform and opening-up, making China ready for greater and faster Socialism developments.

It should be acknowledged, however, that these results were limited in their scope. Due to their initial nature, they were very much products of their time, as some authors readily admitted. These limitations mainly mirrored the scant communication and information channels available at the time. Additionally, many materials were still classified, which made some scholarly research monotonous and uni-dimensional. Another limitation was the analytic paradigm itself. For instance, in Soviet history research, scholars treated Lenin as a "golden 
standard" against which Stalin was evaluated, instead of treating the two men's regimes separately each with its own respective achievements and flaws. Another tendency was to treat the study of the Lenin, Stalin, Khrushchev, and Brezhnev periods as wholly separate and antagonistic existences, ignoring their continuity and similarities.

In addition, the study of the post-Brezhnev period in Soviet history was relatively weak. Because the period was so recent that the data was limited, and research, if possible at all, was limited to introductory materials.

\section{The Study of Russian History from the Collapse of the Soviet Union to the Present in China}

The collapse of the Soviet Union in 1991 marked a paradigm shift in Russian history in China. After 1991, Russia published a great deal of new research and declassified many Soviet-era archives. Russian historical studies in China at this stage was characterized by two goals: one is to translate and sort out the large number of declassified archives after 1991, thereby enriching the historical materials available for further study; the other goal was to examine and re-examine new and old research in the light of these new historical facts. Remarkable achievements have been made in both areas.

In the translation of historical materials, scholars went to Russia to collect new archival materials, and organized staff to translate, edit, and publish a series of documents. ${ }^{1}$

\footnotetext{
1 Chiefly: Shen Zhihua edited the Selected Records of Soviet History (34 volumes), Social Science Literature Press, 2003; Xue Xiantian, Li Jiagu, et al., Compilation of History of Sino-Soviet Relations, Vol: 1917-1924, 1933-1945, and 1945-1949, China Social Science Press, 1993, 1997, 1996; Shen Zhihua, Selected Declassified Russian Files: Sino-Soviet Relations (12 volumes), China Publishing Group East Publishing Center, 2015; Literature Compilation of Relations between China and the Soviet Union (October 1949-December 1951), World Affairs Press, 2009; Literature Compilation of Relations between China and the Soviet Union (1952-1955), World Affairs Press, 2015; The All-Union Communist Party (Bolsheviks) and Chinese Revolution Archival Materials Series, 21 Volumes, translated and edited by the First Research Department of Party History of the Central Committee of the Communist Party of China, of which volumes 1-6 were published by Beijing Library Press in 1998, volumes $7-12$ by the Central Document Press in 2002, volumes 13-17 by History of Chinese Communist Party Publishing House in 2007 and volumes 18-21 by History of Chinese Communist Party Publishing House in 2012. The Russian Archives in the 20th Century, which is translated by the Russian, Eastern European \& Central Asian Studies Institute of the Chinese Academy of Social Sciences, is currently under publication by the People's Press.
} 
In research, Chinese scholars made substantial progress both in pre-October Revolution Russian history and post-revolution Soviet history.

For Pre-Soviet Russian history, a number of new articles were published, some substantially building on previous studies while others touching on previously neglected areas, including ideology, philosophy, culture, rural and agricultural development, and politics.

In this second stage, pre-Soviet Russian thoughts and culture research include, among others: Yao Hai's Road to Russian Culture (Zhejiang People's Press, 1992), Sun Chengmu's One Thousand Year of Russian Culture (Eastern Press, 1995), Dai Guiju's Reformation of the Russian Orthodox Church (1861-1917) (Social Science Literature Press, 2002), Bai Xiaohong's Russian-Slavism (The Commercial Press, 2006), Zhang Jianhua's Introduction to the History of Russian Intellectual Ideology (The Commercial Press, 2008), Yao Hai's (editor-in-chief) Russian Civilization and Diplomacy (Social Sciences Literature Press, 2016).

There have been many publications examining Russia's politics and reform. Important publications include Yao Hai's The Origin of the Modern Russian National Constitutional Movements (Sichuan University Press, 1996), Liu Zuxi's Reform and Revolution - A Study of Russian Modernization (Peking University Press, 2000), Tao Huifen's Modern History of Russian Reform (China Social Sciences Press, 2000), Shao Liying's Fate of Improvement: A History of the Reform of Local Autonomy in Russia (Social Science Literature Press, 2000), Cao Wei'an's New Theory of Russian History (China Social Sciences Press, 2002), Zhao Shiguo's History of Choice and Choice of History: A Study of Late-Modern Russian Revolution and Reform (People's Press, 2006), Liu Xianzhong's The State Duma in Modern Russia: the Establishment and Practice (Social Science Literature Press, 2007), Xie Guoliang's A Study of the Russian Social Revolutionary Party (Social Science Literature Publishing House, 2012), Zhang Zonghua's Reformation and Nobility in the 18th Century Russia (People's Press, 2013 edition), Xu Jinqiu's Study on the Theory and Process of Russian Political Modernization in the 19th Century to the Early 20th Century (Social Science Literature Press, 2018), Zhou Houqin's From City-State to Empire: The Origins of Russian Autocracy (Social Science Literature Press, 2020).

Publications on Russian social research include: peasant communes, reform, and revolution. Select examples include: Mir Tradition and Russian Road of Modernization by Jin Yan and Xian Wu (Central Compilation \& Translation Press, 1996), Fu Shiming's Russian Mir of the Early 20th Century (Guangxi Normal University Press, 2005), Zhang Guangxiang's The Russian Urbanization in the 18th and 19th Centuries (Jilin People's Press, 2006), and Luo Ailin's Study on the Rural Commune in Late Feudal Period of Russia (1649-1861) (Guangxi Normal University Press, 2007). 
Publications on the history of Sino-Russian relations include: Wang Xilong's Brief History of Sino-Russian Relations (Pre-1917) (Gansu Culture Press, 1995), Sun $\mathrm{Xi}$ and Zhang Weihua's Sino-Russian Relations in the Early Qing Period (Shandong Education Press, 1997), Su Fenglin's Study on the History of Early Sino-Russian Relations (Heilongjiang People's Press, 1999), Liu Yuantu's Study on the Eastern Segment of Early Sino-Russian Frontier (China Social Sciences Press, 1993).

After the collapse of the Soviet Union, a large number of documents from the Soviet period were declassified. With these new materials, Soviet-era research was substantially enriched, and quickly a number of publications were issued on the new economic policy, ethnic relations, the Stalin model, the Cold War between the United States and the Soviet Union, the Soviet cultural system, Diplomatic Relations, and historical figures.

First, general and periodic historical research include: Bai Jiancai's The History of Cold War between the United States and the Soviet Union (Shaanxi Normal University Press, 1996), Chen Zhihua's Compendium of Soviet History (1953-1964) (People's Press, 1996), Ma Longshan's The History of the Soviet Cultural System (China Social Sciences Press, 1996), Xing Guangcheng's 70 Years of High-Level Decision Making in the Soviet Union (5 volumes, Xinhua Press, 1998), Chen Zhihua's The Soviet Union during the Brezhnev Period (China Social Science Press, 1998), Shen Zhihua's The History of Sino-Soviet Relations (1917-1991) (Xinhua Press, 2007), Xue Jitian and Jin Dongji co-authored the three-volume History of Sino-Soviet Relations during the Republic of China (History of Chinese Communist Party Publishing House, 2009), Yao Hai's Russian Revolution (People's Press, 2013), Zheng Yifan's Russia Under the New Economic Policy (People's Press, 2013), Xu Tianxin's The Formation of the Stalin Model (People's Press, 2013), Ye Shuzong's Eighteen Years of Brezhnev (People's Press, 2013), Zuo Fengrong's Gorbachev Reform Period (People's Press, 2013), Wen Yi's The History of the Soviet Union (1917-1991) (Shanghai Academy of Social Sciences Press, 2013), Xue Xiaorong et al. compiled the Gorbachev series, including Revolution from the Outside: The Reform of the Soviet Union and the Western Containment Strategy in the Period of Gorbachev, Revolution from the Inside: The Politburo, the Secretariat and the Central Committee of the CPSU in the Period of Gorbachev, Revolution from the Bottom: The Social Democratic Movement in the Period of Gorbachev, and Revolution from the Top: The Political System Reform of the Period of Gorbachev (Tianjin People's Press, 2017).

There had also been much new ethnic research of the Soviet Union, such as Zhao Changqing, Chen Lianbi, Liu Genchen, and Dong Xiaoyang's Study on Ethnic Questions in the USSR (Social Science Literature Press, 1996). Zhang Jianhua's Historical Ethnic Investigation of the Soviet Union (Beijing Normal University Press, 
2002), Zuo Fengrong and Liu Xianzhong, From Soviet Union to Russia: A Study on Ethnic Regional Autonomy (Social Science Literature Press, 2015).

On the foreign policy issue of the Soviet Union, representative publications include: Zhang Shengfa's Stalin and the Cold War (China Social Sciences Press, 2000), Zuo Fengrong's Fatal Missteps: The Evolution and Impact of Soviet Foreign Strategy (World Affairs Press, 2001), Wu Wei's The Soviet Union and the Polish Problem (1939-1945) (World Affairs Press, 2002), Zhao Xuegong's The Turbulence of October: Inside the Cuban Missile Crisis (Tianjin People's Press, 2009 edition), Xu Yuebiao's collection of essays The End of Sino-Soviet Historical Cold Cases (History of Chinese Communist Party Publishing House, 2010), Li Yuzhen's Kuomintang and Comintern (1919-1927) (People's Press, 2012), Liang Qiang's The Soviet Union and the Grand Alliance: A Study Based on New Declassified Files (1941-1946) (China Social Sciences, 2014).

There are also dedicated studies on important historical figures, for example: Zheng Yifan's A Discussion of Bukharin (Central Compilation \& Translation Press, 1997); Jiang Changbin's Political Biography of Stalin (Central Party School Press, 1997).

There are many other studies on other issues, such as Shen Zhihua's New Economic Policy and the Socialization of Agriculture in the Soviet Union (China Social Sciences Press, 1994), Guo Yongsheng's Study of Soviet Dissenters (Inner Mongolia People's Publishing House, 2005), Huang Lifu's Study on the Social Status and the Radical Changes of the Soviet Union (Social Science Literature Press, 2006), Guo Chunsheng's Social Political Stratum and the Upheaval of the Soviet Union (Contemporary World Press, 2006), Hao Yuqing's A Study of the Noninstitutionalized Aspects in the Political Life of the Soviet Union (East China Normal University Press, 2008), Ma Longshan's Cultural Perspective of the Upheaval of the Soviet Union (China Social Sciences Press, 2005), Hao Yuqing's Study on the relationship between the State and Society of the Soviet Union (East China Normal University Press, 2014), Zhao Yuming's “Crime and Punishment” in Siberia: A Study of Japanese Prisoners of War in the Soviet Union (1945-1956) (China Social Sciences Press, 2018), Shen Zhihua's Soviet Experts in China (1948-1960) (China International Radio Press, 2003), Zhang Zeyu's Overseas Learning and Revolution: A Study on the Rise of Studying Abroad in the Soviet Union in the 1920s (People's Press, 2009), and The Reality and Reflection of Chinese Staying in the Soviet during the Early Period of the PRC (East China Normal University Press, 2012) by Zhou Shangwen et al.

Chinese scholars recently began shifting their attention to the historiographical evolution of native Russian historians as an essential contributor to ideological shifts after the collapse of the Soviet Union. Many have pointed out the changes in the content and perspective of historical studies during the political 
transition. Important works in this area include Liu Shuang's A Study of Contemporary Russian History (China Social Sciences Press, 2020).

After the collapse of the Soviet Union, the study of Russian history in Chinese academic circles has gained greater depths and diversities. Continuous history replaced the previous fragmented and often isolated studies of Soviet history and ended the clashing different historical contexts with one another. One of the important features of Chinese publications under this paradigm is the absorption of the latest research in Russia after 1991 and the newly declassified archives. As a result, research topics have become more specific and diverse (China Research Association for Sino-Russia Relations, 1997; Huang, 1999; Liu, 2000; Wu, 2009, 2010; Zhang, 2018, pp. 108-109; Zhang \& Zhou, 2015).

Content-wise, the Russian historiography studies after 1991 have become more abundant in China. Topics include new tasks on existing discussions such as the October Revolution, the new economic policy, the collectivization of agriculture, and Khrushchev's reform; debates on significant historical events such as the "Great Purge"" and "One-Country Socialism". Some have also begun to research significant issues that were previously neglected, such as the Cold War, the Orthodox church, the Russian diaspora, the Slavists and liberalists, the Russian aristocracy, the Narodniks, the Russian Constitutional Movement, the Soviet cultural system, the Soviet dissident movement, and the Soviet privileged class. Post-collapse era publications covering previous staple topics have decreased

2 The debate about the "Great Purge”: Wu Enyuan, Statistical study on the Soviet Union's "Purge in the 1930's", Historical Studies, 2002(5); Zheng Yifan, A study on the scale of "Stalin's Repression", World History, 2003(4); Wu Enyuan, The exaggeration of the "Soviet Union's Purge” during the 1930s - A reply to Mr. Zheng Yifan based on archival materials, History of the World, 2003(4); Zheng Yifan, Concepts and methods in the study of Stalin's Repression, Historical Studies, 2005(5); Ma Shanlong, A reexamination of the number of persecuted in the Soviet Union's “Great Purge”, Historical Studies, 2005(5); Wu Enyuan, The crux and significance of the dispute over the Soviet Union's “Great Purge”, Historical Research, 2006(6).

3 The debate about "One Country Socialism": Zheng Yifan, A new review of the Theory of Building Socialism by One Country, Contemporary World and Socialism, 1995(1); Zheng Yifan, Some problems in the Theory of Building Socialism by One Country, The Issues of Contemporary World Socialism, 1995(4), 1996(1); Chen Kairen, On the Theory of Building Socialism by One Country, A discussion with comrade Zheng Yifan, The Issues of Contemporary World Socialism, 1995(2); Chen Kairen, The key is to seek truth from facts, additional comments on the problems related to "Some problems in the Theory of Building Socialism by One Country", The Issues of Contemporary World Socialism, 1996(4); Zuo Fengrong, More comments on Stalin's "Theory of Building Socialism by One Country": A discussion with comrade Chen Kairen, Problems of Contemporary World Socialism, 1996(2); Lin Jianhua, Historical and dialectical understanding of Stalin's theory of "Building Socialism by One Country”, The Issues of Contemporary World Socialism, 1996(4). 
significantly such as the new economic policy, the October Revolution, and the collectivization of agriculture.

In terms of research methods, most of the studies are guided by Marxist historical materialism, supplemented by modern theories and the history-ofcivilization approach.

\section{Future Research in China's Russian Historical Studies}

To date, despite the outstanding achievements made in the study of Russian history in China, there are still areas for improvement.

First, it has been 30 years since the collapse of the Soviet Union, but the historians in China have scantly examined the Brezhnev period and the Soviet history afterward. The history of Russia after the collapse of the Soviet Union has largely been neglected, which is a gap to fill for future research.

Second, after the collapse of the Soviet Union, Chinese historians have all used archives to varying degrees. However, due to the large number of archival material published after 1991, much of the materials collected have not been thoroughly examined and scrutinized, leaving ample room for much more research. Furthermore, as published documents become categorized, we have all experienced the convenience of accession. Thus, we should make full use of the published archives to further consolidate the historical materials used in Russian historical research. At the same time, interpreting the archives is also gaining prominence, as there has been a growing need to comb out and clarify the facts. The declassified archives have made the previous ambiguous events much clearer. Certain references in previous memoirs and political works have become less reliable as a consequence, and the reason behind certain narratives has also become apparent. Therefore, clarifying and sorting out the historical facts based on archives will also be essential for scholars moving forward.

Third, methodological innovations are also highly important. The study of Russian history in China was first heavily influenced by the Soviet Union and then by European and American countries. Although great achievements have been made after the reform and opening-up and scholars are trying to construct the Chinese discourse of Russian history studies, it seems that much work remains to be done in this area. Our research is still overly reliant on Western or Russian influences to some extent. To change this situation, we must construct our own framework of interpretation and make a breakthrough in methodology and theory. This is especially important as China experiences great changes that have not 
occurred in a century. Theories are the products of reality. And with the constantly changing reality, as China's society and academia grow at an unprecedented pace, we must innovate to keep pace with the tide. This is the direction that Chinese scholars should strive for in the future.

\section{References}

Chen, Q. N. (Ed.). (1991). A review of world history studies since the founding of the People's Republic of China. Beijing: Social Science Literature Press.

China Research Association for Sino-Russia Relations. (1997). The history of Sino-Russian relations: The trend of Sino-Soviet relations post-WWII (1945-1960): Selected academic papers on Sino-Russian (Soviet) relations. Beijing: Social Science Literature Press.

Huang, D. T. (1999). The history of Sino-Russian relations in the twentieth century. Historical Research, (4), 155-156.

Liu, K. M. (1984). A Study of Eastern Europe in the Soviet Union since the founding of the People's Republic of China. Soviet Union and Eastern European Studies, (6), 1-4.

Liu, X. Z. (2000). The debate on the history of the Soviet Union by Chinese scholars since the reform and opening-up of China. Eastern European Central Asian Studies, (6), 85-87.

Wu, E. Y. (2009). A review of the causes of the disintegration of the Soviet Union in recent years by academics in China and abroad. World History, (1), 102-115.

Wu, E. Y. (2010). Several controversial issues about Lenin in recent years. Russian, Eastern European \& Central Asian Studies, (5), 75-79.

Zhang, H. P. (Ed.). (2018). 40 years of Chinese history studies (1978-2018). Beijing: China Social Sciences Press.

Zhang, G. X., \& Zhou, J. Y. (2015). A study of the history of China and Russia over the past 100 years. Journal of Historical Science, (11), 108-128. 